\title{
Effect of Physical Pretreatment on Shrimp Waste for the Chitinase Production under Solid State Fermentation by Trichoderma virens
}

\author{
Rachmawatya*, Madihah M. Salleh ${ }^{\mathrm{b}}$ \\ ${ }^{a}$ Department of Industrial Biotechnology, Faculty of Bioscience and Medical Engineering, Universiti Teknologi Malaysia, 81310 UTM Johor Bahru, Johor, \\ Malaysia \\ ${ }^{b}$ Environmental and Biotechnology (EnviBio) Research Group, Sustainability Research Alliance (SRA). Universiti Teknologi Malaysia, 81310 Johor Bahru, \\ Johor, Malaysia \\ *Corresponding author: rachmawaty.ferry@gmail.com
}

\section{Article history}

Received :5 March 2014

Received in revised form :

19 April 2014

Accepted :3 May 2014

Graphical abstract

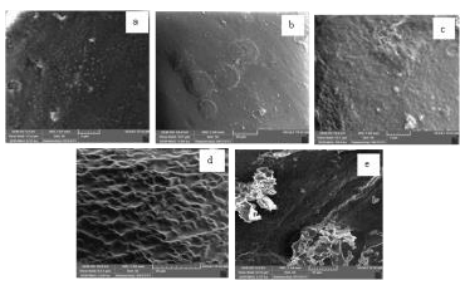

\begin{abstract}
The effect of physical pretreatment and the physical structure of shrimp waste for subsequent use in the production of chitinase were investigated. Physical pretreatment was done using methods of microwave, oven, boiling and sun drying. From the results, it was evident that the structure of the shrimp waste has been affected. Higher chitinase production was found in treated shrimp waste as compared to untreated shrimp waste, due to the configuration changes that allows an increase in chitin's degradability. The scanning electron microscope (SEM) images showed a marked change in the physical appearance of treated shrimp waste as compared to the untreated shrimp waste, especially with microwave pretreatment. Shrimp waste pretreated with microwave was found to produce higher chitinase's activity $(0.194 \mathrm{U} / \mathrm{g}$ IDS) as compared to control (raw shrimp), boiling, oven and sundried pretreatments by increment of 2.9, $1.37,1.2$ and 1.2 fold, respectively.
\end{abstract}

Keywords: Chitinase; shrimp waste; physical pretreatment; solid state fermentation; Trichoderma virens

Abstrak

Kesan rawatan awal fizikal dan struktur fizikal sisa udang untuk kegunaan selanjutnya dalam produksi kitinase telah disiasat. Pra-rawatan fizikal telah dilakukan dengan menggunakan kaedah gelombang mikro, ketuhar, pendidihan dan pemanasan matahari. Keputusan hasil penyelidikan mendapati bahawa struktur dalam sisa kulit udang terjejas. Produksi kitinase tertinggi didapati dalam sisa kulit udang yang dirawat berbanding dengan sisa udang yang tidak dirawat disebabkan oleh perubahan konfigurasi untuk membolehkan peningkatan dalam degradasi kitin. Imej mikroskop imbasan elektron (SEM) menunjukkan perubahan permukaan fizikal pada sisa kulit udang yang dirawat berbanding dengan sisa kulit udang tanpa rawatan, terutamanya dengan meggunakan rawatan awal gelombang mikro. Sisa udang pra-rawatan dengan gelombang mikro telah didapati menghasilkan aktiviti kitinase lebih tinggi $(0.194 \mathrm{U} / \mathrm{g}$ IDS) berbanding dengan kawalan (udang mentah), pendidihan, ketuhar dan rawatan awal sinar matahari dengan kenaikan masing-masing sebanyak 2.9, 1.37, 1.2 dan 1.2 kali ganda.

Kata kunci: kitinase; sisa udang; pra-rawat fizikal, fermentasi keadaan pepejal, virens Trichoderma

(C) 2014 Penerbit UTM Press. All rights reserved.

\subsection{INTRODUCTION}

Bioconversion is defined as the use of biological processes to transform biomass materials from one form to another. These involve the use of enzymes, microbes or other biological agents, alone or in combination [1]. Converting shrimp materials to valuable product is an example of bioconversion. Examples of valuable products from shrimp materials are enzyme production, lactic acid and chitin.

Shrimps are used in major agro-industry in tropical and subtropical countries. Among the products from shrimps are frozen raw shrimp, frozen value-added, shrimp products and frozen cooked shrimp, which generate a large quantity of solid wastes [2]. Solid wastes of shrimp are removed during processing and these account for approximately $50 \%$ of the volume of the raw materials. Due to this, an abundant supply of shrimp wastes is readily available and can be used as a carbon source for bioconversion.

Suresh and Chandrasekaran [3] studied the potential of shrimp waste as a substrate for chitinase production. About $30 \%$ of the shrimp waste's component is chitin. Therefore, shrimp waste has high potential to be bioconverted. However, the 
problem in bioconversion of shrimp materials is the difficulty to produce enzyme as the end product as the chitin contained in shrimp has a highly ordered crystalline structure, which is not easily accessible by enzymes such as chitinase.

Shrimp shell comprises of three major components, with protein as the largest component $(40 \%)$, followed by chitin which contributes $17-40 \%$ and finally, mineral with only $20-$ $30 \%$. Out of the three components, chitin is the most recalcitrant to degradation, whereas other components, because of its highly crystalline structure, are more resistant to hydrolysis than protein and ash [4]. The major factor that determines the effectiveness of the biological conversion process is the chitin content. Therefore, pretreatment is needed in order to enhance chitinase production from shrimp waste materials.

The conventional method of seafood processing includes chitin disposal by ocean dumping, incineration and land filling. However, factors such as cost of transportation and environmental pollution have prompted the search for alternative disposal methods [5]. Bioconversion of waste is probably the most cost-effective and environmental friendly procedure for waste utilization [6]. A number of possibilities for bioconversion of shellfish waste have been reported but each of these have problems in terms of practicability or economically [3].

Solid State Fermentation (SSF) is a low-cost technology fermentation process, particularly suitable for the needs of developing countries [7]. The commonly used substrates for SSF are plant products. Shrimp waste can also be used as substrates for SSF. Utilizing shrimp waste as solid substrates would revolutionize industrial biotechnology, and solve the problem of solid waste disposal.

The objective of this study is to determine the effects of physical pretreatment on the structure of shrimp waste and the subsequent chitinase production through solid state fermentation.

\subsection{MATERIALS AND METHODS}

\subsection{Substrate for SSF}

Shrimp waste was obtained from a market in Johor Bahru, Johor, Malaysia. It was pretreated by using physical methods which include drying, oven heating, boiling and microwave. The material was stored in a dry place at room temperature. It was used as the solid substrate for SSF. Untreated raw shrimp waste was used as control.

\subsection{Microorganism and Inoculum Preparation}

The fungus Trichoderma virens was isolated from a stock culture from Universiti Teknologi Malaysia. It was grown on Potato Dextrose Agar (PDA) and preserved at $300{ }^{\circ} \mathrm{C}$ for 7 days. For inoculums preparation, $10 \mathrm{~mL}$ of sterile distilled water containing $1.0 \%(\mathrm{v} / \mathrm{v})$ of Tween-80 was added as the lubricant. Spores were separated by centrifuging the harvested spores at $4000 \mathrm{rpm}, 4{ }^{\circ} \mathrm{C}$ for 30 minutes. The supernatant was discarded and spores were found as pellet. $10 \%(\mathrm{v} / \mathrm{v})$ of spore suspension containing $1 \times 107$ spores $/ \mathrm{mL}$ was used as inoculums.

\subsection{Solid State Fermentation}

Solid substrate $(5 \mathrm{~g})$ was placed in a $250 \mathrm{~mL}$ Erlenmeyer flask and was added together with basal medium (ammonium sulfate $0.2 \%(\mathrm{w} / \mathrm{v})$, yeast extract $0.1 \%(\mathrm{w} / \mathrm{v}), \mathrm{KH}_{2} \mathrm{PO}_{4} 0.028 \%(\mathrm{w} / \mathrm{v})$, $\left.\mathrm{MgSO}_{4} .7 \mathrm{H}_{2} \mathrm{O} 0.025 \%(\mathrm{w} / \mathrm{v})\right)$. The moisture of the substrate was adjusted to $70 \%$ of humidity at $\mathrm{pH} 5.5$ by the addition of medium. The substrate was sterilized using an autoclave at a temperature of $1210^{\circ} \mathrm{C}$ for 20 minutes and stored at room temperature before it was inoculated. After cooling, the inoculation was carried out with $10 \%$ of inoculums and incubated at $280^{\circ} \mathrm{C}$.

\subsection{Enzyme Extraction}

Fermented samples were collected every $24 \mathrm{~h}$. In each sampling, $1 \mathrm{~g}$ of the sample was drawn out and mixed with $25 \mathrm{~mL}$ of citrate phosphate buffer ( $\mathrm{pH} 4.0)$. The mixture was then placed on a vortex for 1 minute to ensure that enzyme or sugars on the surface were well-mixed with the buffer. Next, the suspension was centrifuged at $4000 \mathrm{rpm}$ at $4^{\circ} \mathrm{C}$ for 20 minutes to separate the solid and liquid phase. The supernatant was used as crude enzyme for various assays.

\subsection{Analytical Procedures}

Chitinase activity was measured by incubating $1 \mathrm{~mL}$ of enzyme solution with $0.5 \mathrm{~g}(\mathrm{w} / \mathrm{w})$ of colloidal chitin in $1 \mathrm{~mL}$ of $0.15 \mathrm{M}$ citrate phosphate buffer $(\mathrm{pH} 4.0)$ at $500^{\circ} \mathrm{C}$ for $1 \mathrm{~h}$. The reaction was terminated by placing the tubes in a boiling water bath for 5 $\min$ and the undigested materials were removed by centrifugation at $4000 \mathrm{rpm}$ for $5 \mathrm{~min}$. The reduced sugar produced was measured colorimetrically using the dinitrosalicylic acid (DNS) reagent with N-acetyl-Dglucosamine as the standard [8]. Colloidal chitin was prepared by following the method of Wasli et al. [9]. One unit (U) of chitinase activity is defined as the amount of enzymes that is required to release $1 \mu \mathrm{mol}$ of $\mathrm{N}$-acetyl- $\beta$ - $\mathrm{D}$-glucosamine per minute under assay conditions.

\subsection{Scanning Electron Microscopy (SEM)}

SEM analysis was conducted using SEM model VEGA TESCAN. For sample preparation, the fibers were dried and mounted onto the stub. Gold coating was done on the surface of the sub by a sputter coater.

\subsection{Result and Discussion}

\subsection{Effect of Various Pretreatment on the Shrimp Waste's Structure}

The effect of pretreatment on shrimp waste's structure was studied using SEM. Figure 1a-1e illustrate the effect of physical pretreatment on the shrimp waste's structure. Marked differences can be seen on the structure of untreated (Figure 1a) and treated shrimp waste (Figure 1b-1e). In the untreated shrimp waste, the shrimp waste structure had unbroken surface and sturdy appearance. Comparing with the other types of treatment, sun dried pretreatment, as shown in Figure 1b, revealed that there was no difference in the structure of the pretreated shrimp waste. Both figures showed similar shrimp waste's morphology. Therefore based on the SEM study, it can be concluded that sun drying shrimp waste did not bring much effect on the structure of shrimp waste.

Oven pretreatment (Figure 1c), microwave pretreatment (Figure 1e) and boiling and crushing pretreatment (Figure 1d) showed altered structures where the unbroken surface and sturdy solid appearance of untreated shrimp waste was replaced with discrete granular structure and the appearance of pores (especially in Figure 1e for microwave pretreatment). Based on 
these result, it is evident that pretreatment altered the structure of the shrimp waste and provides better accessibility for enzymatic attack, that may have change the chitin's crystalline configuration to allow better degradation.

\subsection{Effect of Various Pretreatments on Chitinase's Production}

Crustacean wastes like shrimp waste are predominantly composed of chitin and protein. Shrimp waste exists as large crystalline fiber that is embedded in the matrix of other components such as glucan, mannan, protein and minerals [10]. This compact and complex structure makes it less accessible to chitinolytic enzymes.

The pretreatment gave effect by increasing degradation and hydrolysis, as reported by Rosgaard [11]. Pretreatment before degradation is a strategy to improve enzyme's accesibility and partially alter the chitin crystalline configuration to allow improved degradation. Chitin is completely consists of acetylated polysaccharide, which is very stiff. Chitin is insoluble and can only be made soluble by deacetylation or destruction of the highly crystalline structure of chitin [12].

In this study, five different pretreatments, including a control, were studied. Each pretreatment was extensively studied to understand the capability of different pretreatments in the production of chitinase by solid state fermentation.

Higher chitinase's production was obtained after microwave pretreatment (Table 1). Shrimp waste that underwent microwave pretreatment produced the highest chitinase activity at $0.194 \mathrm{U} / \mathrm{g}$ of substrates after 3 days of fermentation. Goncalves and Schuchardt [13] found that microwave increased the conversion yields in the hydrogenolysis of lignins. Microwave pretreatment has also been found to be beneficial for the extraction of chitin from red crab, although the attempted microwave treatment did not alter the susceptibility of chitin to deacetylation [14]. Pretreatment of chitin by microwave has also resulted in an increase of its enzymatic hydrolysis by cabbage chitinase [15].

The second highest chitinase's activity was achieved by oven pretreatment, followed by boiling pretreatment, sundried pretreatment and finally untreated with chitinase's activity of $0.158,0.141,0.151$ and 0.0665 , respectively.

The synergetic effect of the physical pretreatment on chitinase's production was investigated. Overall, microwave pretreatment resulted in the improvement in chitinase's production. The SEM image (Figure 1e) shows changes in the morphology of chitin. While the control sample shows unbroken and solid sturdy appearance (Figure 1a), the SEM image of microwave-treated sample shows discrete granular structure. The higher rate obtained in the case of treated chitin, presumably reflects reduction in mass transfer constrains for the enzyme accessing the substrate Pretreatment allows enzymatic and microbial access to the chitin while reduction in chitin's crystallinity increases the rate of attack by chitinase on the chitin. Enhanced chitinase's accessibility can be achieved by breaking down the crystalline fiber because the relative ease of chitin hydrolysis provides an ideal avenue for creating larger pores in the microfibers. Pretreatment can increase in both the pore volume's accessibility and the specific surface area [7].
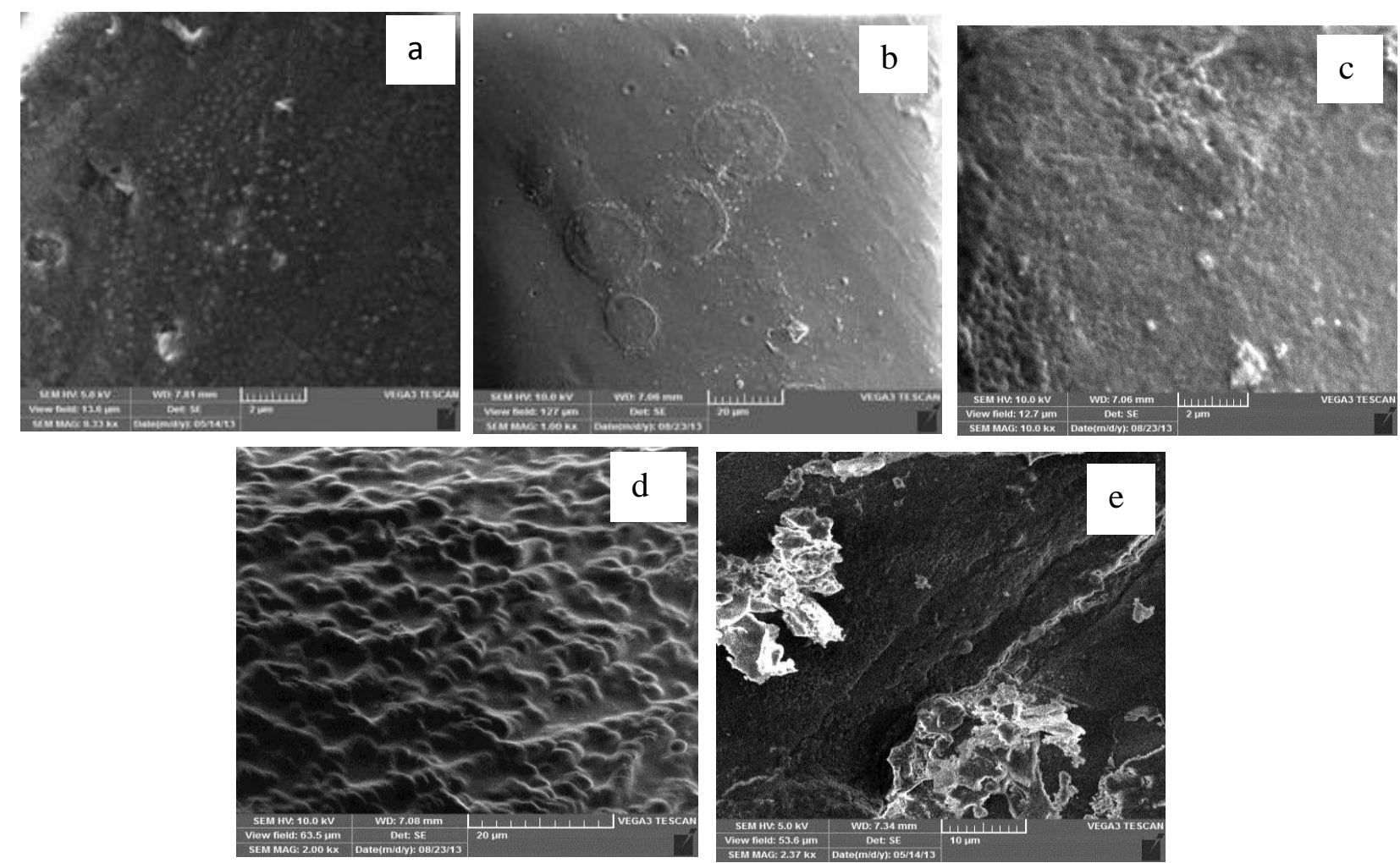

Figure 1 SEM images of shrimp waste after different pretreatments (magnification x1000 and x2000): (a) untreated, (b) sundried, (c) oven, (d) boling and crushing, and (e) microwave pretreatments 
Table 1 Effect of different pretreatments of shrimp waste on the production of chitinase

\begin{tabular}{lccccc}
\hline \multicolumn{1}{c}{ Pretreatment } & $\begin{array}{c}\text { Maximum chitinase } \\
\text { activity (U/g) }\end{array}$ & Day & $\begin{array}{c}\text { Maximum specific } \\
\text { activity (U/mg) }\end{array}$ & $\begin{array}{c}\text { Day } \\
\text { Productivity } \\
\text { (U/mg/day) }\end{array}$ \\
\hline Boiling and crushing & 0.141 & 5 & 0.012 & 5 & 0.0023 \\
Microwave & 0.194 & 3 & 0.017 & 3 & 0.0058 \\
$\begin{array}{l}\text { Oven } \\
\text { Sun-drying }\end{array}$ & 0.158 & 3 & 0.012 & 3 & 0.00405 \\
$\begin{array}{l}\text { Raw shrimp waste } \\
\text { untreated) }\end{array}$ & 0.151 & 9 & 0.013 & 2 & 0.0065 \\
\hline
\end{tabular}

\subsection{CONCLUSION}

Microwave pretreatment is the best way to alter the physical structure of the shrimp wastes, as well as for higher chitinase's production by Trichoderma virens. Chitinase's production with this method was $0.194 \mathrm{U} / \mathrm{g}$ IDS. Pretreatment of shrimp waste is important to enhance and accelerate enzyme substrate reaction for obtaining products that can contribute to shrimp wastes' added-value.

\section{Acknowledgements}

This work was financially supported by GUP Research grant QJ130000.2545.05H13 by Universiti Teknologi Malaysia and Ministry of Higher Education Malaysia (MOHE).

\section{References}

[1] A. Hassan, M. A., Umi Kalsom, M. S., Abdullah, N., Shirai, Y. 2008. J. Trop. Agric. Fd. Sc. 36: 000-000.
[2] W. Choorit, W. Patthanamanee, S. Manurakchinakom. 2008. Bioresour. Technol. 99: 6168-6173.

[3] P. V. Suresh, M. Chandrasekaran. 1998. J. Microbiol. Biotechnol. 14: 655-660.

[4] J. Synowiecki, N. A. Al-Khateeb. 2003. Crit. Rev. Food Sci. Nutr. 43(2): $145-171$.

[5] Vyas, P. R., Desphande, M. V. 1991. J. Appl. Microbiol. 37: 267-275.

[6] M.G. Healy, C.R. Romo, R. Bustos. 1994. Resour. Conser. Recy. 11: 139-147.

[7] A. Pandey. 2003. Biochem. Eng. J. 13: 81-84.

[8] G. L. Miller. 1959. Anal. Chem. 31: 426-431

[9] A.S. Wasli, Madihah, M.S., Suraini, A.Z., O. Hassan. 2009. Biotechnol. Bioprocess Eng. 14: 781-787.

[10] M .O. P. Crespo, M. V. Martinez, J. L. Hernandez and M. A. L Yusty. 2006. J. Chromatogr. A. 116: 189-192.

[11] Rosgaard, S. Pedersen, J. R. Cherry, P. Harris, A. S. Meyer. 2006 Biotechnol. Prog. 22:493-498.

[12] Vincent. 2002. Composites Part A. 33: 1311-1315.

[13] A.R. Goncalves, U. Schuchardt. 2002. Appl. Biochem. Biotechnol. 98 815-832.

[14] A. Pajak, I. Kolodziefska, A. Debogorska, M. Malesa Ciecwiez. 1998 Bull. Sea Fisheries Inst. 1: 29-39.

[15] Roy, K. Mondal and M. N. Gupta. 2003. Biotechnol. Prog. 19: 16481653. 